\title{
Saat Terbaik Pemberian Suplementasi Zat Besi pada Bayi 0 Bulan sampai 6 Bulan
}

\author{
Harapan Parlindungan Ringoringo*, Iskandar Wahidiyat**, BambangSutrisna **, Rahayuningsih \\ Setiabudy**, Rulina Suradi**, Rianto Setiabudy**, Sapatawati Bardososono** \\ *Bagian Anak Fakultas Kedokteran Universitas Lambung Mangkurat, Banjarmasin \\ **Fakultas Kedokteran Universitas Indonesia Rumah Sakit Dr. Cipto Mangunusumo, Jakarta
}

Latar belakang. Anemia defisiensi besi (ADB) merupakan salah satu masalah kesehatan gizi di Indonesia. Survei kesehatan rumah tangga (SKRT) tahun 2001 menunjukkan prevalensi ADB pada bayi 0-6 bulan $61,3 \%$.

Tujuan. Mengetahui berapa insidens defisiensi besi dengan atau tanpa anemia, dan kapan mulai terjadi deplesi besi atau defisiensi besi sebelum terjadi ADB pada bayi berusia 0-6 bulan.

Metode. Desain penelitian adalah studi kohort prospektif dengan pembanding eksternal. Di antara 211 bayi yang ikut penelitian, terdiri dari 143 bayi yang lahir dari ibu tanpa anemia dan 68 bayi yang lahir dari ibu dengan anemia. Pemeriksaan darah tepi lengkap, gambaran darah tepi, saturasi transferin (ST) dilakukan saat bayi berusia 0, 1, 2, 3, 4, 5, dan 6 bulan. Diagnosis ADB berdasarkan 1) kadar $\mathrm{Hb}<14 \mathrm{~g} / \mathrm{dL}$ untuk usia 0-3 hari, $<11 \mathrm{~g} / \mathrm{dL}$ untuk usia 1 bulan, $<10 \mathrm{~g} / \mathrm{dL}$ untuk usia 2-6 bulan, 2) mikrositik dan atau hipokrom, 3) kadar $\mathrm{Hb}$ meningkat setelah diberi terapi besi, 4) $\mathrm{RDW}>14 \%$, 5) Indeks Mentzer $>13$; 6) Indeks RDW $>22,0$. Deplesi besi bila ST $<30 \%$ untuk usia 0-1 bulan, ST $<21 \%$ untuk usia 2-6 bulan. Defisiensi besi bila ST $<20 \%$ untuk usia $0-1$ bulan, ST $<16 \%$ untuk usia $2-6$ bulan.

Hasil. Insidens deplesi besi, defisiensi besi, ADB berturut-turut 28,0, 27,0, dan 40,8\%; artinya 95,8\% bayi mempunyai status besi bermasalah. Insidens deplesi besi, defisiensi besi, ADB paling tinggi pada bayi berusia 0 bulan, berturut-turut 9,5, 14,2, dan $11,8 \%$.

Kesimpulan. Insidens deplesi besi, defisiensi besi, ADB paling tinggi pada bayi berusia 0 bulan. Suplementasi zat besi elemental dengan dosis $1 \mathrm{mg} / \mathrm{kg} /$ hari hendaknya diberikan pada semua bayi aterm sejak lahir. (Sari Pediatri 2008;10(3):163-70).

Kata kunci: ADB, insidens, suplementasi besi

\footnotetext{
Alamat Korespondensi:

Dr. dr. Harapan Parlindungan Ringoringo, Sp.A(K).

RSUD Banjarbaru. Jl. Palang Merah No.2 Banjarbaru - Kalimantan

Selatan 70712. Email : hprspa@yahoo.com
}

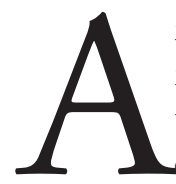

nemia defisiensi besi (ADB) masih merupakan salah satu masalah kesehatan gizi utama di dunia, di Asia Tenggara, terutama menunjukkan prevalensi ADB pada balita, bayi $<1$ tahun, dan bayi 0-6 bulan berturut-turut adalah 48,1, 
55, dan 61,3\%. ${ }^{1}$ Susilowati $\mathrm{dkk}^{2}$ tahun 2004 dalam penelitiannya terhadap 317 bayi berusia 2-4 bulan di Bogor dan Kabupaten Buleleng Bali mendapatkan prevalensi ADB 56,5\%. Tingginya prevalensi defisiensi besi atau ADB pada balita atau anak di bawah satu tahun tidak terlepas dari tingginya prevalensi defisiensi besi atau ADB pada wanita hamil. Data SKRT tahun 2001 menunjukkan prevalensi ADB pada wanita hamil adalah 40,1\%. ${ }^{1}$ Prevalensi ADB meningkat dengan bertambah usia gestasi, 10, 14, dan 33\% berturut-turut pada trimester I, II, dan III. ${ }^{3}$

Faktor risiko lain untuk terjadinya $\mathrm{ADB}$ pada bayi adalah jenis kelamin bayi, apakah bayi minum ASI atau susu formula yang telah difortifikasi besi, pendidikan ibu yang rendah, status ekonomi keluarga yang rendah, dan jumlah paritas (jarak kelahiran dekat) yang tinggi. ${ }^{1-8}$ Bayi membutuhkan 270-280 mg ferrum $(\mathrm{Fe})$ pada tahun pertama kehidupan, sekitar 0,8 mg Fe/hari. ${ }^{9}{ }^{910}$ Susu murni mempunyai kandungan $\mathrm{Fe}$ sangat rendah, yaitu $0,8 \mathrm{mg}$ per $1000 \mathrm{~mL}$ dan jumlah Fe yang diserap hanya $10 \%$. Pengganti ASI (PASI) yang sudah diperkaya Fe (iron fortified milk) mempunyai kandungan Fe 11-12 mg per $1000 \mathrm{~mL}$ sedangkan jumlah Fe yang diserap hanya 4\%. Dalam ASI mengandung 0,3 mg Fe per 1000 $\mathrm{mL}$ namun jumlah $\mathrm{Fe}$ yang diserap dapat mencapai $50 \% .^{3,11,12,13}$

Mengingat kebutuhan Fe yang tinggi, efek jangka panjang defisiensi besi, dan kesulitan mendiagnosis deplesi besi atau defisiensi besi dengan atau tanpa anemia pada bayi berusia 0-6 bulan, American Associations of Pediatrics merekomendasikan pemberian suplementasi zat besi pada bayi yang lahir aterm paling lambat pada usia 4 bulan; sedangkan untuk bayi yang lahir preterm diberikan paling lambat pada usia 2 bulan. ${ }^{14,15}$ Di Norwegia semua bayi baru lahir mendapat suplementasi zat besi sejak usia 6 minggu sampai usia 1 tahun dengan dosis $18 \mathrm{mg} /$ hari. ${ }^{16}$ Penelitian Dijkhuizen $\mathrm{dkk}^{17}$ di Bogor Jawa Barat tahun 1999 memperlihatkan bahwa dari 90 bayi berusia 4,2 bulan yang mendapat suplementasi Fe elemental 10 $\mathrm{mg} /$ hari selama 6 bulan ternyata yang mengalami ADB hanya $28 \%$ dibandingkan 87 bayi berusia 4,2 bulan yang tidak mendapat suplementasi Fe angka ADB $66 \%$. Beberapa penelitian menunjukkan bahwa kadar $\mathrm{Hb}$, VER, feritin, saturasi transferin mulai menurun pada usia 2-3 bulan. ${ }^{10,18,19}$ Akan tetapi kapan mulai terjadinya deplesi besi, defisiensi besi tanpa anemia dan ADB belum diketahui pasti.
Tujuan penelitian untuk mengetahui insidens defisiensi besi dengan atau tanpa anemia, dan kapan mulai terjadi deplesi besi atau defisiensi besi sebelum terjadi ADB sehingga dapat diketahui saat terbaik pemberian suplementasi zat besi pada bayi berusia 0 bulan sampai 6 bulan.

\section{Metode}

Desain penelitian kohort prospektif dengan pembanding eksternal (studi kohort ganda). Penelitian dilaksanakan di wilayah Kotamadya Banjarbaru Kalimantan Selatan, mulai bulan Juli 2006 sampai dengan Oktober 2007. Telah mendapat ethical clearance (lolos kaji etik) dari Komite Etik FKUI Jakarta, dan semua subjek penelitian menyetujui inform consent yang diberikan oleh peneliti.

Subjek terjangkau adalah semua ibu dan bayinya yang memenuhi kriteria inklusi dan tidak memenuhi kriteria eksklusi, didapat secara consecutive (berurutan) sampai jumlah subjek yang diperlukan terpenuhi. Kriteria inklusi untuk ibu apabila bersedia diikutsertakan dalam penelitian, tidak menderita sakit berat selama kehamilannya, dan tidak menderita perdarahan antepartum. Kriteria eksklusinya apabila menderita penyakit hematologik-onkologi. Kriteria inklusi untuk bayi orang tua mengijinkan bayinya diikutsertakan dalam penelitian, lahir bugar (warna kulit merah, laju nadi $>100 \mathrm{x} /$ menit, menangis kuat), lahir aterm dengan berat lahir $\geq 2500 \mathrm{~g}$, tidak menderita kelainan kongenital mayor. Kriteria eksklusi apabila menderita sakit berat selama periode penelitian, menderita penyakit hematologik-onkologi selama periode penelitian, selama periode penelitian karena suatu hal - orang tua tidak bersedia bayinya diikutsertakan lagi dalam penelitian.

Ibu dikelompokkan menjadi kelompok ibu tanpa anemia, bila $\mathrm{Hb} \geq 11 \mathrm{~g} / \mathrm{dL}$, dan kelompok ibu dengan anemia, bila $\mathrm{Hb}<11$ g/dL. ${ }^{9,20,21}$ Jumlah bayi yang diikutsertakan dalam penelitian 211 bayi, terdiri dari 143 bayi yang lahir dari kelompok ibu tanpa anemia dan 68 bayi dari kelompok ibu dengan anemia. Pada bayi dilakukan pemeriksaan darah tepi lengkap, gambaran darah tepi, saturasi transferin, feritin serum, dan sTfR saat bayi berusia $0,1,2,3,4$, 5, dan 6 bulan; darah diambil dari vena di fossa cubiti atau di dorsum manus. Bahan darah segera dikirim ke laboratorium Prodia; sebagian sampel darah untuk 
pemeriksaan saturasi transferin, feritin dan sTfR disimpan di laboratorium Prodia untuk kemudian dikirim ke laboratorium SEAMEO TROPMED Jakarta dan laboratorium patologi klinik RSCM di Jakarta.

Diagnosis ADB pada bayi ditegakkan berdasarkan kadar $\mathrm{Hb}$ lebih kecil dari batas bawah nilai normal $(<14 \mathrm{~g} / \mathrm{dL}$ untuk usia $0-3$ hari, $<11 \mathrm{~g} / \mathrm{dL}$ untuk usia 1 bulan, $<10 \mathrm{~g} / \mathrm{dL}$ untuk usia 2-6 bulan), gambaran darah tepi menunjukkan mikrositik dan atau hipokrom, kadar $\mathrm{Hb}$ meningkat setelah diberi terapi besi elemental selama 2 bulan, RDW $>14 \%$, Indeks Mentzer $>13 ; 6$ ) Indeks RDW >22,0. . $^{111,12,22}$ Diagnosis ADB ditegakkan bila kriteria pada 3 butir pertama terpenuhi ditambah $\geq 1$ dari 3 kriteria pada butir 4, 5, dan 6. Diagnosis deplesi besi ditegakkan berdasarkan kadar $\mathrm{Hb}$ normal

Tabel 1. Karakteristik demografi ibu

\begin{tabular}{|c|c|c|c|c|}
\hline \multicolumn{2}{|l|}{ Variabel } & $\begin{array}{l}\text { Ibu tanpa anemia } \\
\qquad \mathrm{n}=143\end{array}$ & $\begin{array}{l}\text { Ibu dengan anemia } \\
n=68\end{array}$ & $p$ \\
\hline \multicolumn{2}{|c|}{ Umur ibu (tahun, n\%) } & $29,2(5,7)$ & $28,5(17-44)$ & 0,41 \\
\hline \multirow{2}{*}{\multicolumn{2}{|c|}{ Masa gestasi (minggu, rerata, SD) }} & $39,6(1,0)$ & $39,7(0,7)$ & 0,16 \\
\hline & & $\rightarrow$ Median 40 & $\rightarrow$ Median 40 & \\
\hline \multicolumn{5}{|c|}{ Paritas ibu (n, \%) } \\
\hline \multicolumn{2}{|c|}{$0-2$} & $113(79,0)$ & $51(75,0)$ & 0,51 \\
\hline \multirow{2}{*}{\multicolumn{2}{|c|}{$\begin{array}{l}>2 \\
\text { Pendidikan ibu (n. \%) }\end{array}$}} & $30(21,0)$ & $17(25,0)$ & \\
\hline & \multicolumn{4}{|c|}{ Pendidikan ibu (n, \%) } \\
\hline \multicolumn{2}{|c|}{ Rendah } & $21(14,7)$ & $14(20,6)$ & 0,52 \\
\hline \multicolumn{2}{|l|}{ Menengah } & $87(60,8)$ & $37(54,4)$ & \\
\hline \multicolumn{2}{|l|}{ Tinggi } & $35(24,5)$ & $17(25,0)$ & \\
\hline \multicolumn{5}{|c|}{ Pekerjaan ibu (n, \%) } \\
\hline \multicolumn{2}{|c|}{ Ibu tidak bekerja } & $119(83,2)$ & $51(75,0)$ & 0,16 \\
\hline \multicolumn{2}{|c|}{ Ibu bekerja } & $24(16,8)$ & $17(25,0)$ & \\
\hline \multicolumn{5}{|c|}{ Status ekonomi keluarga (n, \%) } \\
\hline \multicolumn{2}{|c|}{ Miskin } & $122(85,3)$ & $56(82,4)$ & 0,68 \\
\hline \multicolumn{2}{|c|}{ Tidak Miskin } & $21(14,7)$ & $12(17,6)$ & \\
\hline \multicolumn{2}{|c|}{ Berat badan sebelum hamil (kg, rerata, SD) } & $50,1(9,4)$ & $50,0(10,7)$ & 0,90 \\
\hline \multicolumn{2}{|c|}{ Berat badan saat melahirkan (kg, rerata, SD) } & $60,8(10,3)$ & $60,6(12,8)$ & 0,91 \\
\hline \multicolumn{5}{|c|}{ Perawatan antenatal $(\mathrm{n}, \%)$} \\
\hline \multicolumn{2}{|c|}{ Bukan dokter } & $89(62,2)$ & $45(66,2)$ & 0,58 \\
\hline \multicolumn{2}{|c|}{ Dokter ahli kebidanan } & $54(37,8)$ & $23(33,8)$ & \\
\hline \multicolumn{2}{|c|}{ Jumlah kunjungan (rerata, SD) } & $8,3(2,8)$ & $7,6(2,6)$ & 0,04 \\
\hline \multirow{2}{*}{\multicolumn{2}{|c|}{$\begin{array}{l}\text { antenatal selama hamil } \\
\text { Jenis persalinan }(\mathrm{n}, \%)\end{array}$}} & $\rightarrow$ Median 9 & $\rightarrow$ Median 8 & \\
\hline & & & & \\
\hline \multicolumn{2}{|c|}{ Spontan } & $111(77,6)$ & $49(72,1)$ & 0,27 \\
\hline \multicolumn{2}{|c|}{ Dengan tindakan } & $32(22,4)$ & $19(27,9)$ & \\
\hline \multicolumn{5}{|c|}{ Laboratorium (rerata, SD) } \\
\hline$\sum$ Eritrosit & $\left(10^{6} / \mathrm{uL}\right)$ & $4,4(0,4)$ & $3,8(0,5)$ & $<0,001$ \\
\hline $\mathrm{Ht}$ & $(\%)$ & $37,4(2,6)$ & $31,1(2,9)$ & $<0,001$ \\
\hline VER & $\left(u^{3}\right)$ & $86,1(5,6)$ & $81,6(7,5)$ & $<0,001$ \\
\hline RDW & $(\%)$ & $15,1(1,7)$ & $16,0(2,1)$ & $<0,001$ \\
\hline $\mathrm{Hb}$ & $(\mathrm{g} / \mathrm{dL})$ & $12,2(1,0)$ & $10,0(0,9)$ & $<0,001$ \\
\hline HER & (pg) & $28,2(2,2)$ & $26,2(2,8)$ & $<0,001$ \\
\hline KHER & $(\mathrm{g} / \mathrm{dL})$ & $32,8(0,9)$ & $32,1(1,0)$ & $<0,001$ \\
\hline Trombosit & $\left(10^{3} / \mathrm{uL}\right)$ & $266,7(29,1)$ & $242,7(69,6)$ & 0,49 \\
\hline Leukosit & $\left(10^{3} / \mathrm{uL}\right)$ & $11,7(4,8)$ & $11,4(4,7)$ & 0,64 \\
\hline sTfR & $(\mathrm{mg} / \mathrm{L})$ & $9,0(4,4)$ & $10,4(6,3)$ & 0,08 \\
\hline Feritin & $(\mathrm{ug} / \mathrm{L})$ & $30,9(40,5)$ & $26,8(40,6)$ & 0,45 \\
\hline
\end{tabular}


untuk usia tertentu, saturasi transferin $<30 \%$ untuk usia $0-1$ bulan, dan saturasi transferin $<21 \%$ untuk usia 2-6 bulan. Diagnosis defisiensi besi ditegakkan berdasarkan kadar $\mathrm{Hb}$ normal untuk usia tertentu, saturasi transferin $<20 \%$ untuk usia $0-1$ bulan, saturasi transferin $<16 \%$ untuk usia 2-6 bulan. ${ }^{7,12,23}$ Bila bayi menderita $\mathrm{ADB}$ maka bayi mendapat terapi oral $\mathrm{Fe}$ selama 2-4 bulan dengan dosis Fe elemental $4-5 \mathrm{mg} /$ $\mathrm{kgBB} / \mathrm{hari}, 1-3$ kali sehari, sebelum minum susu atau makan. Data diolah dengan program SPSS 15.0 dan STATA Intercool 9.2

\section{Hasil}

Ibu yang dapat diikutsertakan sebagai subjek penelitian 220 orang, dan hanya 9 orang $(4,09 \%)$ yang tidak diikutkan dalam analisis karena 7 orang menolak melanjutkan penelitian serta 2 orang data laboratorium tidak lengkap. Pada kelompok ibu tanpa anemia, 143 bayi yang terdiri dari 83 bayi laki-laki dan 60 bayi perempuan; dan pada kelompok ibu dengan anemia ada 68 bayi yang terdiri dari 38 bayi laki-laki dan 30 bayi perempuan. Karakteristik demografi subjek penelitian (ibu) tertera pada Tabel 1. Dari Tabel 1 tampak bahwa karakteristik demografi kedua kelompok hampir sama (secara statistik tidak ada perbedaan bermakna, $p>0,05)$, sehingga kedua kelompok dapat diperbandingkan pada variabel yang memang akan diteliti. Pada hasil laboratorium terlihat indeks eritrosit kedua kelompok memang berbeda $(p<0,001)$, sehingga kedua kelompok ini layak untuk dibandingkan apakah bayi yang dilahirkan cenderung lebih mudah menderita defisiensi besi atau tidak.

Tabel 2. Insidens ADB pada bayi berusia 0-6 bulan

\begin{tabular}{lccc}
\hline Status ibu & Bayi dengan ADB & Bayi tanpa ADB & Jumlah \\
\hline Ibu dengan anemia (n, \%) & $30(44,1)$ & $38(55,9)$ & $68(100)$ \\
Ibu tanpa anemia (n, \%) & $56(39,2)$ & $87(60,8)$ & $143(100)$ \\
\hline Jumlah (n, \%) & $86(40,8)$ & $125(59,2)$ & $211(100)$ \\
\hline
\end{tabular}

Tabel 3. Insidens deplesi besi dan defisiensi besi pada bayi berusia 0-6 bulan

\begin{tabular}{lcccccc}
\hline \multirow{2}{*}{ Status ibu } & \multicolumn{5}{c}{ Bayi } \\
\cline { 2 - 7 } & $\begin{array}{c}\text { Deplesi } \\
\text { Besi (+) }\end{array}$ & $\begin{array}{c}\text { Deplesi } \\
\text { Besi (-) }\end{array}$ & \multirow{2}{*}{ Jumlah } & $\begin{array}{c}\text { Defisiensi } \\
\text { Besi }(+)\end{array}$ & $\begin{array}{c}\text { Defisiensi } \\
\text { Besi }(-)\end{array}$ & \multirow{2}{*}{ Jumlah } \\
\hline Ibu dengan anemia (n, \%) & $22(32,4)$ & $46(67,6)$ & $68(100)$ & $11(16,2)$ & $57(83,8)$ & $68(100)$ \\
Ibu tanpa anemia (n, \%) & $37(25,9)$ & $106(74,1)$ & $143(100)$ & $46(32,2)$ & $97(67,8)$ & $143(100)$ \\
\hline Jumlah (n, \%) & $59(28,0)$ & $152(72,0)$ & $211(100)$ & $57(27,0)$ & $154(73,0)$ & $211(100)$ \\
\hline
\end{tabular}

Tabel 4. Insidens ADB, defisiensi besi, deplesi besi menurut umur pada bayi 0-6 bulan

\begin{tabular}{llcccccccc}
\hline ADB & Ibu & \multicolumn{7}{c}{ Umur bayi (bulan) } & Jumlah \\
\cline { 2 - 8 } & & 0 & 1 & 2 & 3 & 4 & 5 & 6 & \\
\cline { 2 - 8 } & Dengan anemia & 9 & 7 & 7 & 4 & 2 & 0 & 1 & 30 \\
& Tanpa anemia & 16 & 16 & 17 & 5 & 1 & 0 & 1 & 56 \\
& Jumlah & 25 & 23 & 24 & 9 & 3 & 0 & 2 & 86 \\
\hline Defisiensi besi & Dengan anemia & 4 & 0 & 0 & 2 & 4 & 1 & 0 & 11 \\
& Tanpa anemia & 26 & 0 & 1 & 5 & 10 & 4 & 0 & 46 \\
& Jumlah & 30 & 0 & 1 & 7 & 14 & 5 & 0 & 57 \\
\hline Deplesi besi & Dengan anemia & 8 & 1 & 2 & 1 & 8 & 1 & 1 & 22 \\
& Tanpa anemia & 12 & 3 & 2 & 7 & 5 & 6 & 2 & 37 \\
& Jumlah & 20 & 4 & 4 & 8 & 13 & 7 & 3 & 59 \\
\hline
\end{tabular}


Pada Tabel 2 tertera insidens ADB pada bayi berusia 0 bulan sampai 6 bulan dari ibu dengan anemia dan ibu tanpa anemia berturut-turut $44,1 \%$ dan $39,2 \%$; dan secara keseluruhan dari semua bayi, insidens ADB 40,8\%. Pada 125 bayi yang tidak menderita ADB dilakukan pemeriksaan saturasi transferin untuk menetapkan apakah seorang bayi menderita deplesi besi, defisiensi besi, atau normal. Berdasarkan hasil pemeriksaan saturasi transferin didapatkan 59 bayi menderita deplesi besi, 57 bayi menderita defisiensi besi, dan 9 bayi normal tanpa deplesi besi maupun defisiensi besi.

Tabel 3 memperlihatkan insidens deplesi besi pada bayi berusia 0 bulan sampai 6 bulan dari ibu dengan anemia dan ibu tanpa anemia berturut-turut $32,4 \%$ dan 25,9\%. Secara keseluruhan, dari 211 bayi, insidens deplesi besi 28,0\%. Insidens defisiensi besi pada bayi berusia 0 bulan sampai 6 bulan dari ibu dengan anemia dan ibu tanpa anemia berturut-turut $16,2 \%$ dan 32,2\%. Secara keseluruhan dari 211 bayi insidens defisiensi besi 27,0\%.

Pada Tabel 4 tertera insidens ADB cenderung lebih sering terjadi pada bayi berusia $0-2$ bulan [72 bayi $(83,7 \%)$ dari 86 bayi ADB], baik pada bayi lahir dari ibu dengan anemia maupun lahir dari ibu tanpa anemia. Dari Tabel 2 dan Tabel 4 terlihat insidens ADB pada bayi umur 0,1 , dan 2 bulan berturut-turut adalah $11,8,10,9$, dan $11,3 \%$.

\section{Pembahasan}

Karakteristik ibu kelompok ibu dengan anemia hampir sama dengan ibu pada kelompok ibu tanpa anemia. Insidens $\mathrm{ADB}$ pada bayi berusia 0 bulan sampai 6 bulan dari ibu dengan anemia dan ibu tanpa anemia berturutturut $44,1 \%$ dan $39,2 \%$, secara keseluruhan, insidens ADB 40,8\%. Penemuan ini tidak berbeda dengan apa yang dilaporkan oleh Ringoringo ${ }^{24}$ dalam penelitian terdahulu Agustus 2005 terhadap 104 bayi berusia 0-6 bulan di RSUD Banjarbaru yang menemukan prevalensi ADB 38,5\%.

Sejauh ini belum ada dilaporkan insidens deplesi besi atau defisiensi besi pada bayi berusia 0 bulan sampai 6 bulan, karena memang "gold standar" cutoff point kadar feritin, sTfR maupun indeks sTfR-F untuk penetapan seorang bayi deplesi besi atau defisiensi besi pada bayi 0-6 bulan belum ada. Karena itu untuk menetapkan apakah seorang bayi menderita deplesi besi, defisiensi besi, atau normal dilakukan pemeriksaan saturasi transferin. Pemeriksaan saturasi transferin dianggap sebagai "gold standar" karena sampai saat ini pemeriksaan ini dapat membedakan deplesi besi dari defisiensi besi dan batasan angka yang dipilih adalah yang terendah ditemukan di dalam kepustakaan. ${ }^{7,23}$ Kemungkinan pengaruh variasi diurnal dapat disingkirkan (paling tidak sangat diminimalkan) oleh karena semua sampel darah bayi diambil pada pagi hari. Ervasti $\mathrm{dkk}^{23}$ menemukan bahwa indeks sTfR-F berkorelasi dengan saturasi transferin dan indeks eritrosit; dan feritin dan sTfR berkorelasi secara bermakna dengan saturasi transferin.

Pemeriksaan saturasi transferin dilakukan pada 125 bayi yang tidak menderita ADB. Insidens deplesi besi pada bayi dari ibu dengan anemia dan ibu tanpa anemia berturut-turut $32,4 \%$ dan $25,9 \%$, secara keseluruhan insidens deplesi besi adalah 28,0\%, dan paling tinggi insidensnya pada bayi berusia 0 bulan $9,5 \%$ dari 211 bayi. Insidens deplesi besi lebih sering terjadi pada bayi umur 0 bulan baik pada bayi yang lahir dari ibu dengan anemia maupun pada bayi yang lahir dari ibu tanpa anemia, insidens menurun dan mulai meningkat lagi pada saat bayi berusia 3-4 bulan, dan lebih tinggi pada bayi yang lahir dari ibu dengan anemia [ 9 daripada bayi yang lahir dari ibu tanpa anemia di antara 37 bayi].

Insidens defisiensi besi pada bayi dari ibu dengan anemia dan ibu tanpa anemia berturut-turut adalah $16,2 \%$ dan $32,2 \%$, secara keseluruhan insidens $27,0 \%$, dan paling tinggi pada bayi baru lahir 14,2\%. Insidens defisiensi besi lebih sering terjadi pada bayi baru lahir baik yang lahir dari ibu dengan anemia maupun dari ibu tanpa anemia. Insidens kemudian menurun dan mulai meningkat lagi pada usia 3-4 bulan. Insidens lebih tinggi pada bayi yang lahir dari ibu dengan anemia daripada bayi yang lahir dari ibu tanpa anemia. Ervasti $\mathrm{dkk}^{23}$ melaporkan 9 bayi $(4,5 \%)$ dari 199 bayi baru lahir menderita defisiensi besi (batasan defisiensi besi adalah bila saturasi transferin $<30 \%$ ).

Berdasarkan data yang disajikan, perlu dipertanyakan kembali apakah anggapan bahwa cadangan besi yang diperoleh bayi sejak dalam kandungan ibunya dan yang diperoleh dari ASI cukup untuk memenuhi kebutuhan Fe bayi sampai usia 4-6 bulan sehingga tidak akan terjadi defisiensi besi atau ADB?25 Sudah banyak penelitian yang mengungkapkan fakta bahwa ADB sudah terjadi dalam rentang usia bayi 0-6 bulan. Pertanyaannya adalah mengapa bayi sudah menderita deplesi besi, defisiensi besi atau ADB sejak lahir ? Pada 
penelitian kami 25 kasus ADB saat bayi lahir 16 bayi dari kelompok ibu tanpa anemia dan 9 bayi dari kelompok ibu dengan anemia. Kemungkinan disebabkan karena dari kelompok ibu tanpa anemia, terdapat ibu-ibu yang menderita defisiensi besi. Terbukti bahwa dari 143 ibu tanpa anemia dijumpai 49 ibu (34,3\%) yang menderita defisiensi besi, dan 94 ibu mempunyai status besi normal. Dari 49 ibu yang menderita defisiensi besi ini ternyata bayi yang dilahirkannya sudah menderita ADB pada 8 bayi, deplesi besi pada 5 bayi, defisiensi besi pada 5 bayi, dan status besi normal pada 31 bayi. Pada 94 ibu dengan status besi normal ternyata 8 bayi yang dilahirkannya sudah menderita $\mathrm{ADB}$, deplesi besi pada 7 bayi, defisiensi besi pada 21, dan normal pada 58 bayi.

Singla $\mathrm{dkk}^{26}$ melaporkan bahwa ibu hamil yang menderita $\mathrm{ADB}$ dan berlangsung lama akan menyebabkan cadangan Fe neonatus rendah. Georgieff $\mathrm{dkk}^{27}$ melaporkan bahwa apapun yang menyebabkan peningkatan masa eritrosit fetus seperti insufisiensi plasenta dan diabetes melitus dalam kehamilan akan menyebabkan kadar feritin berkurang dan kadar sTfR meningkat di darah tali pusat. Agarwal $\mathrm{dkk}^{28}$ Erdem $\mathrm{dkk}^{29}$ Ziaei $\mathrm{dkk}^{20}$ menyatakan bahwa bayi baru lahir yang lahir aterm dari ibu dengan anemia mempunyai kadar feritin dan saturasi transferin yang lebih rendah dibandingkan bayi baru lahir yang lahir aterm dari ibu tanpa anemia. Demikian juga Kelly $\mathrm{dkk}^{30}$ Fenton $\mathrm{dkk}^{31}$ melaporkan bahwa bayi baru lahir yang lahir aterm dari ibu dengan defisiensi besi tanpa anemia mempunyai kadar feritin yang lebih rendah dibandingkan bayi baru lahir yang lahir aterm dari ibu dengan status besi yang normal.

Dengan adanya fakta bahwa ADB, deplesi besi, dan defisiensi besi sudah ada sejak bayi lahir maka perlu segera dilakukan tindakan pencegahan agar tumbuh kembang bayi dapat berlangsung optimal. Siegel $\mathrm{dkk}^{33}$ dalam penelitiannya menyimpulkan bahwa faktor risiko usia bayi adalah faktor risiko utama yang dapat menyebabkan kecenderungan seorang bayi akan menderita ADB atau defisensi besi. Semakin bertambah usia si bayi semakin besar risikonya menderita defisiensi besi atau ADB. Jadi pencegahan deplesi besi, defisensi besi dan ADB harus lebih awal, bahkan sejak bayi baru lahir.

Respons kenaikan nilai hemoglobin setelah pemberian zat besi pada bayi yang menderita ADB merupakan bukti paling kuat bahwa si bayi benarbenar menderita ADB. Sampai akhir penelitian, jumlah bayi yang menderita $\mathrm{ADB}$ ada 86 orang. Pemberian zat besi elemental $4-5 \mathrm{mg} / \mathrm{kgBB} /$ hari selama $2-3$ bulan dimulai pada saat terjadi $\mathrm{ADB}$ dapat memulihkan kadar hemoglobin bayi menjadi normal. Jumlah bayi yang mempunyai kadar hemoglobinnya pulih dalam 1, 2, dan 3 bulan terapi berturut-turut adalah 58,18 , dan 10 bayi. Kemudian pada semua bayi dengan kadar hemoglobin telah normal, terapi zat besi dilanjutkan selama 2 bulan untuk mengisi depo zat besi di dalam tubuh.

Penelitian kami membuktikan bahwa bila ADB dapat dideteksi secara dini dan segera diterapi dengan zat besi maka status besi akan segera pulih sehingga dapat mencegah gangguan tumbuh kembang bayi terutama perkembangan kognitif dan psikomotor. Penelitian Soesmalijah ${ }^{33}$ pada 176 anak prasekolah berusia 3-6 tahun anak dari ibu pemetik teh yang tinggal di perkebunan teh di daerah kecamatan Pangalengan kabupaten Bandung membuktikan, pemberian zat besi elemental $50 \mathrm{mg}$ sehari selama 8 minggu pada anak yang menderita $\mathrm{ADB}$ dan defisiensi besi tanpa anemia memperlihatkan perbaikan pada proses kognitif khusus. Kognitif khusus yaitu perhatian dan belajar konsep awal dibandingkan pada anakanak yang sehat (status besi baik). Kadar Hb, feritin, saturasi transferin, dan eritrosit protoporfirin anak yang menderita defisiensi besi tanpa anemia meningkat secara bermakna dibandingkan sebelum diberikan terapi zat besi.

Penelitian Steinmacher $\mathrm{dkk}^{34}$ membandingkan pemberian suplementasi zat besi $2-4 \mathrm{mg} / \mathrm{kgBB} / \mathrm{hari}$ pada 164 bayi berat lahir sangat rendah $<1301 \mathrm{~g}$. Kelompok pertama (90 bayi) mendapat suplementasi zat besi sejak usia 14 hari, sementara kelompok kedua (74 bayi) mendapat suplementasi zat besi pada usia 61 hari. Kemudian dilakukan penilaian pada saat bayi berusia 5,3 tahun. Pada kelompok pertama ditemukan kelainan neurologis yang lebih sedikit, gangguan motorik kasar yang lebih sedikit, tanpa cacat fisik dan mental yang lebih banyak, cacat fisik berat yang lebih sedikit, dan lebih banyak yang masuk ke sekolah regular dibandingkan pada anak-anak dari kelompok kedua. Tidak dilaporkan adanya efek samping zat besi.

Penelitian Braekke $\mathrm{dkk}^{35}$ pada 21 bayi berat lahir sangat rendah $<1500 \mathrm{~g}$ dengan usia gestasi $<32$ minggu yang diberikan suplementasi zat besi ferofumarat sebanyak $18 \mathrm{mg} /$ hari selama 1 minggu pada usia 6 minggu menunjukkan bahwa kadar 8-isoprostane dalam urin dan hidroperoksida total dalam plasma (sebagai 
petanda stress oksidatif), dan anti oksidan (vitamin $\mathrm{C}$, vitamin $\mathrm{E}$, glutation) tidak berubah bermakna dibandingkan sebelum pemberian suplementasi besi. Juga dilaporkan tidak ada efek samping obat zat besi. Hal yang sama dilaporkan oleh Miller $\mathrm{dkk}^{36}$ yang meneliti bayi prematur dengan masa gestasi 24-32 minggu yang diberikan suplementasi ferosulfat dengan dosis 3-12 mg/kgBB/hari, tidak menunjukkan adanya stress oksidatif dan tidak ada efek samping obat. Dosis toksik Fe elemental adalah $30 \mathrm{mg} / \mathrm{kgBB}$, dan akan mengakibatkan kematian pada dosis $60 \mathrm{mg} / \mathrm{kgBB} .^{3}$

\section{Kesimpulan}

Mengingat tingginya insidens $\mathrm{ADB}$ (40,8\%), deplesi besi $(28,0 \%)$ dan defisiensi besi $(27,0 \%)$ atau dengan kata lain $95,8 \%$ status besi bayi tidak cukup dalam rentang 6 bulan, terutama pada bayi berusia $0-2$ bulan. Mengingat dampak positif pemberian suplementasi zat besi dan tidak ada/ minimal efek samping obat, maka suplementasi zat besi berupa besi elemental dengan dosis $1 \mathrm{mg} / \mathrm{kg} / \mathrm{hari}$ hendaknya diberikan pada semua bayi yang lahir aterm sejak lahir.

\section{Daftar Pustaka}

1. Untoro R, Falah TS, Atmarita, Sukarno R, Kemalawati R, Siswono. Anemia gizi besi. Dalam: Untoro R, Falah TS, Atmarita, Sukarno R, Kemalawati R, Siswono, penyunting. Gizi dalam angka sampai dengan tahun 2003. Jakarta: Depkes RI; 2005. h. 41-4.

2. Susilowati H, Suwarti S, Ernawati F, Sukraniti DP, Putri SD, Sudirman H. Faktor-faktor yang mempengaruhi kejadian anemia pada bayi usia 2,3 dan 4 bulan. Bogor: Puslitbang Gizi dan Makanan Balitbang Kesehatan Depkes; 2005.

3. Dallman PR. Iron deficiency anemia : a synthesis of current scientific knowledge and U.S. recommendations for prevention and treatment. Dalam: Earl R, Woteki $\mathrm{CE}$, penyunting. Iron deficiency anemia : recommended guidelines for prevention, detection, and management among U.S children and women of childbearing age. Didapat dari: http://www.nap.edu/catalog/2251.html.

4. Pee S, Bloem MW, Sari M, Kiess L, Yip R, Kosen S. The high prevalence of low hemoglobin concentration among Indonesian infants aged 3-5 months is related to maternal anemia. J Nutr 2002;132:2215-21.
5. Oski FA. Iron deficiency in infancy and childhood. N Engl J Med 1993; 329: 190-3.

6. Vasquez-Seoan P, Windom R, Pearson HA. Disappearance of iron deficiency anaemia in a high risk infant population given supplemental iron. N Engl J Med 1985;313:1239-40.

7. Yip R, Walsh KM, Goldfarb MG, Binkin MJ. Declining prevalence of anaemia in childhood in a middleclass setting: a paediatric success story? Pediatrics 1987;80:330-4.

8. Tunnessen WW Jr, Oski FA. Consequences of starting whole cow milk at 6 months of age. J Pediatr 1987;111:813-6.

9. Helen Keller International (Indonesia). Iron deficiency anemia in Indonesia. Report of the policy workshop on iron deficiency anemia in Indonesia. Jakarta: 1997. h. 1-16.

10. Lundstorm UL, Siimes MA, Dallman PR. At what age does iron supplementation become necessary in lowbirth-weight infants? J Pediatr 1977;91:878-83.

11. Andrews NC. Iron deficiency and related disorders. Dalam: Greer JP, Foerster J, Lukens JN, Rodgers GM, Paraskevas F, Glader B, penyunting. Wintrobe's Clinical Hematology. Edisi kesebelas, vol 1. Philadelphia:Lippincott William \& Wilkins; 2004. h. 979-1009.

12. Glader B. Anemia: general considerations. Dalam: Greer JP, Foerster J, Lukens JN, Rodgers GM, Paraskevas F, Glader B, penyunting. Wintrobe's clinical hematology. Edisi kesebelas, vol 1. Philadelphia:Lippincott William \& Wilkins; 2004. h. 947-78.

13. Soegijanto S, Ugrasena. Anemia defisiensi besi pada bayi dan anak. Jakarta: Yayasan Penerbitan IDI;2004. h. 1-23.

14. American Academy of Pediatrics (Committee on Nutrition). Nutritional needs of low-birth-weight infants. Pediatrics 1985;75:976-86.

15. Franz AR, Mihatsch WA, Sander S, Kron M, Pohlandt F. Prospective randomized trial of early versus late enteral iron supplementation in infants with a birth weight of less than 1301 grams. Pediatrics 2000;106:700-6.

16. Braekke K, Bechensteen AG, Halvorsen BL, Blomhoff R, Haaland K, Staff AC. Oxidative stress markers and antioxidant status after oral iron supplementation to very low birth weight infants. J Pediatr 2007;151:23-8.

17. Dijkhuizen MA, Wieringa FT, West CE, Martuti S, Muhilal. Iron and zinc supplementation in Indonesian infants: effects on micronutrient status and growth. Dalam: Dijkhuizen MA, Wieringa FT, penyunting. Vitamin A, iron, and zinc deficiency in Indonesia. Micronutrient interactions and 
effects of supplementation. Wageningen: Wageningen University; 2001. h. 67-82.

18. Rios E, Lipschitz DA, Cook JD, Smith NJ. Relationship of maternal and infant iron stores as assessed by determination of plasma feritin. Pediatrics 1975;55:694-9.

19. Saarinen UM, Siimes MA. Developmental changes in serum iron, total iron-binding capacity, and transfering saturation in infancy. J Pediatr 1977;91:875-7.

20. Ziaei S, Hatefnia E, Togeh Gh. Iron status in newborns born to iron-deficient mothers. Iran J Med Sci 2002; 28:62-4.

21. Kilbride J, Baker TG, Parapia LA, Khoury SA, Shuqaidef, Jerwood D. Anaemia during pregnancy as a risk factor for iron-deficiency anaemia in infancy: a case-control study in Jordan. Int J Epid 1999;28:461-8.

22. Smith H. Normal values and appearance. Dalam: Smith $\mathrm{H}$, penyunting. Diagnosis in paediatric haematology. New York:Churchill Livingstone; 1996. h. 1-33.

23. Ervasti M, Kotisaari S, Senkilampi U, Heinonen S, Punnonen K. The relationship between red blood cell and reticulocyte indices and serum markers of iron status in the cord blood of newborns. Clin Chem Lab Med 2007;45:1000-3.

24. Ringoringo HP, Windiastuti E. Profil parameter hematologik dan anemia defisiensi zat besi bayi berumur 0-6 bulan di RSUD Banjarbaru. Sari Pediatri 2006;7:214-8.

25. Yip R, Dallman PR. Iron. Dalam: Ziegler EE, Filer LJ, penyunting. Present knowledge in nutrition. Edisi ketujuh. Washington DC:ILSI Press; 1996. h. 277-92.

26. Singla PN, Tyagi M, Shankar R, Dash D, Kumar A. Fetal iron status in maternal anemia. Acta Paediatr 1996;85:1327-30.

27. Georgieff MK, Landon MB, Mills MM. Abnormal iron distribution in infants of diabetic mothers: spectrum and maternal antecedents. J Pediatr 1990;117:455-61.
28. Agarwal RMD, Tripathi AM, Agarwal KN: Cord blood hemoglobin, iron and ferritin status in maternal anemia. Acta Paediatr Scand 1983; 72: 545-8.

29. Erdem A, Erdem M, Arslan M, Yazici G, Eskandari R, Himmetoglu O: The effect of maternal anemia and iron deficiency on fetal erythropoiesis: comparison between serum erythropoietin, hemoglobin and ferritin levels in mothers and newborns. J Matern Fetal Neonatal Med 2002; 11:329-32.

30. Kelly AM, MacDonald DJ, Mc Dougall AN: Observations on maternal and fetal ferritin concentrations at term. Br J Obstet Gynaecol 1978;85:338-43.

31. Fenton V, Cavill I, Fisher J: Iron stores in pregnancy. $\mathrm{Br}$ J Haematol 1977;37:145-9.

32. Siegel EH, Stoltzfus RJ, Khatry SK, LeClerq S, Katz J, Tielsch JM. Epidemiology of anemia among 4-to 17month children living in South Central Nepal. Eur J Clin Nutr 2006;60:228-35.

33. Soesmalijah S. Pengaruh zat besi terhadap kognisi. Disertasi. Jakarta: Universitas Indonesia; 1991. h. 216-35.

34. Steinmacher J, Pohlandt F, Bode H, Sander S, Kron M, Franz AR. Randomized trial of early versus late enteral iron supplementation in infants with a birth weight of less than 1301 grams: Neurocognitive development at 5.3 years' corrected age. Pediatrics 2007;120:538-46.

35. Braekke K, Bechensteen AG, Halvorsen BL, Blomhoff R, Haaland K, Staff AC. Oxidative Stress Markers and Antioxidant Status after Oral Iron Supplementation to Very Low Birth Weight Infants. J Pediatr 2007;151:23-8.

36. Miller SM, McPherson RJ, Juul SE. Iron sulfate supplementation decrease Zinc protoporphyrin to heme ratio in premature infants. J Pediatr 2006; 148:44-8.

37. Ringoringo HP. Disertasi. Pendekatan diagnostik status besi bayi berusia 0 bulan sampai 6 bulan di Banjarbaru: saat terbaik pemberian suplementasi zat besi. Jakarta: Universitas Indonesia; 2008. h. 99-101. 